\title{
FAMILY HEALTH EDUCATION SEBAGAI PENCEGAHAN PENULARAN COVID-19 PADA KELUARGA DENGAN KOMORBID DIABETES MELLITUS
}

\author{
Susi Wahyuning Asih ${ }^{1)}$, Sri Wahyuni ${ }^{2}$ \\ Fakultas Ilmu Kesehatan, Universitas Muhammadiyah Jember, Jember, Indonesia \\ email: susiwahyuningasih@unmuhjember.ac.id
}

\begin{abstract}
Abstrak
Covid-19 adalah penyakit yang saat ini menjadi permasalahan global karena penularannya yang sangat masif. Penyakit diabetes mellitus merupakan penyakit yang sangat rentan terpapar atau beresiko tertular Covid-19 yang banyak terjadi di masyarakat. Penerapan protokol kesehatan yang ketat adalah upaya untuk mencegah penularan Covid-19. Keluarga memiliki peran yang penting dalam memberikan pengetahuan, kesadaran dan memperbaiki perilaku kesehatan pada anggota keluarganya. Tujuan penelitian adalah untuk mengetahui model family health education terhadap penerapan protokol kesehatan pencegahan penularan Covid-19 pada klien dengan komorbid diabetes mellitus. Penelitian eksprerimental ini menggunakan one group pretest-postest design. Populasi penelitian adalah keluarga yang memiliki anggota penderita DM. Sampel penelitian sebanyak 31 orang di Desa Sumberwaru Kecamatan Sukowono Kabupaten Jember yang diambil secara Nonprobability purposive sampling. Data dianalisis menggunakan Paired T-Test dengan derajat signifikasi 95\%. Hasil penelitian mendapatkan rata-rata penerapan protokol kesehatan pencegahan penularan Covid-19 sebelum intervensifamily health education adalah 35,32 dan setelah intervensi sebesar 41,71 (terjadi peningkatan sebesar 6,39). Ada perbedaan signifikan dari sebelum dan sesudah intervensi $(P$ $<0,05)$. Model family health education dapat meningkatkan penerapan protokol kesehatan pencegahan penularan covid 19 pada keluarga dengan komorbid diabetes mellitus.
\end{abstract}

Kata kunci: family health education, protokol kesehatan, pencegahan covid-19, komorbid diabetes mellitus

\begin{abstract}
Covid-19 has become a global problem currently because of its massive transmission. Diabetes mellitus comorbid disease was a risk factor for Covid-19. The implementation of strict health protocols was an effort to prevent the transmission of Covid-19. Family has an important role in providing knowledge, awareness and improving health behavior to family members. The aim of the study was to determine the effect of the family health education model on health protocols to prevent transmission of covid 19 in clients with comorbid diabetes mellitus. This experimental research used one group pretest-postest design. The population was family that has members with DM. The sample size of the research was 31 people in Sumberwaru Village, Sukowono, Jember taken by nonprobability purposive sampling. Data were analyzed using Paired T-Test. The results found that the implementation of health prevention of Covid-19 transmission before the intervention was 35.32 and after the intervention was 41.71 (an increase of 6.39). There was a significant difference before and after the intervention $(P<0.05)$. So, family health education model can improve the application of health protocols to prevent transmission of Covid-19 in family with comorbid diabetes mellitus.
\end{abstract}

Keywords: family health education, health protocols, covid-19 prevention, diabetes mellitus comorbid

\section{PENDAHULUAN}

Coronavirus disease 2019 (COVID-19) telah menjadi permasalahan dunia karena jumlah kasusnya yang terus mengalami peningkatan setiap harinya. COVID-19 disebabkan oleh virus yang dikenal dengan severa acute respiratory syndrome coronavirus-2 (SARS-CoV-2) (Burhan dkk., 2020;
Meng et al., 2020). World Health Organization (WHO) sejak bulan Maret yang lalu telah menetapkan wabah ini sebagai pandemi global. Penularan virus Corona telah dipahami bersama melalui kontak dekat dan droplet, walaupun sekarang dimungkinkan dapat disebarkan melalui udara atau airborn. Orang yang berisiko terinfeksi adalah yang berhubungan dekat dengan orang yang 
positif Covid-19. Tindakan pencegahan merupakan kunci penerapan dipelayanan kesehatan dan masyarakat. Diantara tindakan pencegahan di masyarakat adalah dengan menjaga kebersihan tangan menggunakan hand sanitizer jika tangan tidak terlihat kotor, cuci tangan dengan sabun jika tangan terlihat kotor, menghindari menyentuh mata, hidung dan mulut, memakai masker dan menjaga jarak (minimal 1 meter) dari orang lain. Perilaku lain yang perlu diterapkan adalah etika ketika batuk atau bersin yaitu dengan menutup hidung dan mulut dengan lengan atas bagian dalam.

Penyakit komorbid (penyakit penyerta) Diabetes Mellitus (DM) merupakan faktor risiko dari infeksi SARS-CoV-2 atau Covid-19 yang banyak di masyarakat selain hipertensi (Susilo dkk., 2020). Diabetes Mellitus (DM) adalah suatu kelompok penyakit metabolik dengan ciri utama hiperglikemia. Diabetes Mellitus (DM) merupakan salah satu penyakit yang telah menjadi masalah kesehatan di dunia. Di Indonesia Diabetes Mellitus (DM) adalah penyakit yang menempati urutan keempat terbanyak di dunia yaitu 8,4 juta setelah India 31,7 juta, Cina 20,8 juta, dan Amerika Serikat 17,7 juta jiwa. WHO memperkirakan jumlah penderita Diabetes Mellitus (DM) di Indonesia akan meningkat hingga dua sampai tiga kali lipat pada tahun 2030 dari 8,4 juta mencapai 21,3 juta orang (John Lede dkk, 2018).

Keluarga adalah sebuah sistem yang terdiri dari ayah, ibu dan anak atau semua individu yang tinggal di dalam rumah tangga. Diantara anggota keluarga saling berinteraksi, interelasi dan interdependensi dalam rangka mencapai tujuan bersama. Keluarga juga merupakan sebuah sistem yang terbuka, sehingga keluarga dapat dipengaruhi oleh sistem diatasnya (suprasistemnya) dalam hal ini lingkungan dan mayarakat. Namun sebaliknya sebagai sebuah subsistem dari lingkungan atau masyarakat, keluarga dapat mempengaruhi masyarakat. Dalam kaitannya dengan kesehatan, keluarga memiliki peran dan fungsi yang sangat penting dalam membentuk manusia sebagai anggota masyarakat yang sehat. Kesadaran seluruh anggota keluarga

sangat penting karena fungsi keluarga adalah mempertahankan kesehatan keluarga agar tetap memiliki produktivitas yang tinggi dan keluarga mampu mengenal dan mengatasi masalah kesehatan serta merawat anggota keluarganya yang sakit (Matheos \& Rottie, 2018). Family Health Education atau biasa kita sebut pendidikan kesehatan keluarga merupakan kegiatan pendidikan yang dilakukan dengan cara menyebarkan pesan, menanamkan keyakinan sehingga keluarga mampu memiliki kesadaran, mendapatkan pengetahuan dan mampu menerapkan anjuran yang ada hubungan dengan kesehatan (Fitriani, 2011).

Dari pengamatan dan wawancara sementara mengenai pandemi Covid-19 dengan masyarakat yang anggota keluarganya komorbid (memiliki penyakit penyerta yaitu Diabetes Mellitus (DM) menunjukkan masih rendahnya pengetahuan tentang Covid-19, penularan, pencegahan, perilaku keluarga dalam menerapkan protokol kesehatan, terutama yang mempunyai komorbid Diabetes Mellitus (DM) sehingga keluarga terkesan kurang disiplin dalam menerapkan protokol kesehatan untuk mencegah penularan Covid-19. Kondisi ini membutuhkan intervensi segera untuk mencegah laju peningkatan angka Covid-19 terutama pada keluarga dengan komorbid DM melalui family health education. Hal ini membuktikan bahwa family health education menunjang penerapan protokol kesehatan dalam usaha pencegahan penularan Covid-19 utamanya pada klien dan keluarga yang salah satu anggota keluarganya dengan komorbid diabetes mellitus.

\section{METODE PENELITIAN}

Jenis penelitian ini adalah eksperimental lapangan dengan menggunakan one group pretestpostest design. Populasi penelitian adalah keluarga yang memiliki anggota penderita Diabetes Mellitus (DM). Sampel penelitian sebanyak 31 orang di Desa Sumberwaru Kecamatan Sukowono Kabupaten Jember. Pengambilan sampel dengan teknik Nonprobability purposive sampling. Variabel bebas adalah model family health education dan variabel terikat adalah penerapan protokol kesehatan pencegahan penularan Covid-19. Penelitian dimulai dengan identifikasi keluarga penderita DM, kemudian dilakukan pengukuran variabel (terikat) sebelum dan setelah intervensi. Pengukuran data dilakukan menggunakan skala rubrik dengan 5 katagori, yaitu: buruk (skor 1), kurang (skor 2), cukup (skor 3), baik (skor 4) dan sangat baik (skor 5). Data yang diperoleh dianalisis menggunakan Paired T-Test dengan derajat signifikasi 95\%.

\section{HASIL DAN PEMBAHASAN}

Berikut disajikan data umum responden berdasarkan umur, jenis kelamin, pendidikan, pekerjaan, penghasilan keluarga, jumlah anggota keluarga dan informasi pencegahan Covid-19. 
Tabel 1. Data Umum Responden $(n=31)$ yang berada di Desa Sumberwaru Sukowono Jember

\begin{tabular}{|c|c|c|c|}
\hline \multicolumn{2}{|c|}{ Variabel } & \multirow{2}{*}{$\frac{F}{13}$} & \multirow{2}{*}{$\begin{array}{c}\text { Persentase }(\%) \\
41,9\end{array}$} \\
\hline Umur (tahun) & $20-30$ & & \\
\hline & $31-40$ & 7 & 22,6 \\
\hline & $41-50$ & 7 & 22,6 \\
\hline & $>51$ & 4 & 12,9 \\
\hline \multirow[t]{2}{*}{ Jenis Kelamin } & Laki-laki & 11 & 35,5 \\
\hline & Perempuan & 20 & 64,5 \\
\hline \multirow[t]{4}{*}{ Pendidikan } & SD/Tidak Sekolah & 16 & 51,6 \\
\hline & SLTP & 9 & 29,0 \\
\hline & SLTA & 5 & 16,1 \\
\hline & Sarjana & 1 & 3,2 \\
\hline \multirow[t]{3}{*}{ Pekerjaan } & Petani & 5 & 16,1 \\
\hline & Swasta & 24 & 77,4 \\
\hline & Tidak bekerja & 2 & 6,5 \\
\hline \multirow[t]{3}{*}{ Penghasilan Keluarga (Rp) } & $2.355 .662,90$ & 6 & 19,4 \\
\hline & $<2.355 .662,90$ & 20 & 64,5 \\
\hline & $>2.355 .662,90$ & 5 & 16,1 \\
\hline \multirow[t]{3}{*}{ Jumlah Anggota Keluarga } & 2 & 2 & 6,5 \\
\hline & 3 & 12 & 38,7 \\
\hline & $>3$ & 17 & 54,8 \\
\hline \multirow[t]{2}{*}{ Informasi Pencegahan Covid-19 } & Ada/mendapat & 22 & 71,0 \\
\hline & Tidak ada & 9 & 28,0 \\
\hline
\end{tabular}

Berdasarkan tabel 1, responden paling banyak berusia 20-30 tahun, berjenis kelamin perempuan 20 orang, tingkat pendidikan SD atau tidak bersekolah, pekerjaan swasta, penghasilan rata-rata $<$ dari 2 juta per bulan, dan jumlah anggota keluarga $>3$ orang sebesar 17 responden.

Tabel 2. Penerapan Protokol Pencegahan Penularan Covid-19 Sebelum dan Sesudah Intervensi Family Health Education $(\mathrm{n}=31)$

\begin{tabular}{llllll}
\hline $\begin{array}{c}\text { Variabel } \\
\text { (Penerapan } \\
\text { protokol } \\
\text { pencegahan } \\
\text { penularan } \\
\text { Covid-19) }\end{array}$ & Mean & SD & SE & $\begin{array}{c}\text { Beda } \\
\text { Mean }\end{array}$ & $\begin{array}{c}\mathrm{P} \\
\text { value }\end{array}$ \\
\hline $\begin{array}{l}\text { Sebelum } \\
\text { Intervensi }\end{array}$ & 35,32 & 4,362 & 0,783 & 6,39 & 0,000 \\
$\begin{array}{l}\text { Sesudah } \\
\text { Intervensi }\end{array}$ & 41,71 & 2,795 & 0,502 & & \\
\hline
\end{tabular}

Berdasarkan tabel 2 menunjukkan bahwa terjadi peningkatan rata-rata penerapan protokol pencegahan penularan Covid-19 sebelum dan sesudah intervensi sebesar 6,39. Hasil uji paired $t$ test didapatkan $\mathrm{p}=0,000(\mathrm{P}<0,05)$, artinya terdapat perbedaan yang signifikan pada penerapan protokol pencegahan penularan Covid-19 antara sebelum dan setelah intervensi family health education.
Family Health Education adalah model pendidikan keluarga dalam bentuk pemberian informasi kesehatan yang diimpelementasikan kepada anggota keluarga. Family Health Education bertujuan untuk merubah perilaku keluarga dengan menumbuhkan dan mengembangkan aspek pengetahuan, pemahaman dan kesadaran, yang pada akhirnya akan menghasilkan perubahan sikap dan tindakan, dalam hal ini mengenai perawatan dan pengobatan suatu penyakit atau pencegahan penularan penyakit seperti pandemi Covid-19 saat ini.

Penerapan Family Health Education berdasarkan hasil penelitian menunjukkan data pada usia responden dewasa awal (18-35 tahun), bahkan masih ada yang berusia 21 tahun. Tingkat pendidikan lulusan SD sebanyak 16 keluarga dan sebanyak 22 keluarga sudah pernah mendapatkan informasi terkait penularan Covid-19, namun keluarga belum mengerti jika ketidakpatuhan keluarga terhadap protokol kesehatan yang akan mengakibatkan penularan Covid-19 terutama pada pasien dengan Diabetes Mellitus DM. Penerapan protokol kesehatan belum maksimal mereka lakukan karena penghasilan keluarga yang dibawah 2 juta menuntut mereka untuk bekerja lebih keras sehingga tidak memikirkan protokol kesehatan $3 \mathrm{M}$ memakai masker, menjaga jarak, dan mencuci tangan dengan sabun.

Penghasilan keluarga yang kurang dari 2 juta dengan pekerjaan terbanyak wiraswasta dapat menyebabkan penurunan motivasi untuk mengikuti 
aturan pencegahan Covid-19. Faktor sosial ekonomi rendah maupun menengah keatas sangat mungkin tertular virus corona. Data usia responden, pada periode dewasa awal cenderung masih sangat produktif sehingga sangat mudah untuk menerima informasi kesehatan, namun pada usia ini juga cenderung masih memiliki sifat ego dan dapat mengalihkan tanggung jawab kepada anggota keluarga lainnya.

Kondisi ini didukung oleh pendapat yang menyatakan bahwa pengaruh usia ini sangat berperan penting dalam menyelesaikan masalah salah satunya masalah kesehatan yang berada dalam keluarga (Buana, 2020). Selain usia, pendidikan juga menjadi faktor responden untuk memahami penjelasan yang disampaikan peneliti, sehingga perlu menyampaikan informasi dan penjelasan yang mudah dipahami oleh responden. Kondisi ini didukung oleh pendapat yang menyatakan bahwa seseorang yang memiliki tingkat pendidikan tinggi biasanya akan mempunyai keinginan untuk mengembangkan dirinya, sedangkan yang mempunyai tingkat pendidikan rendah cenderung mempertahankan tradisi yang ada atau mengikuti kebudayaan yang sudah lama diterapkan dan tidak mengembangkan potensi yang dimiliki (Chandra, 2012).

Tidak hanya itu, penghasilan rendah bagi sebuah keluarga sangat mempengaruhi kebutuhan keluarga karena harus menyesuaikan dengan kebutuhan terutama jika anggota keluarga menderita penyakit yang mengharuskan rutin kontrol ke dokter sehingga perlu biaya tambahan diluar kebutuhan pokok. Kondisi ini didukung oleh pendapat dari (Setiarni, Sutomo\& Hariyono, 2011) bahwa keluarga yang memiliki status ekonomi rendah ataupun tinggi akan meningkatkan risiko untuk terkena penyakit Diabetes Mellitus sebesar 1,655 kali lebih besar. Jika faktor tersebut sudah menjadi dasar untuk keluarga bisa berubah perilakunya (Ali, 2010).

Tidak hanya keluarga tetapi penderita Diabetes Mellitus penting untuk mengetahui bagaimana cara penularan virus tersebut, karena hal ini sangat mempengaruhi perilaku pasien dan keluarga.

Hasil post-test memiliki peningkatan skor dari pre-test, yang artinya ada perubahan pada perilaku keluarga terkait penerapan protokol kesehatan. Pada saat peneliti mengambil post-test kemudian dengan mengobservasi langsung bagaimana penerapan protokol kesehatan di rumah masingmasing responden ternyata yang paling banyak terlihat adalah tidak berjabat tangan dengan orang lain, mencuci tangan sebelum dan sesudah memegang sesuatu, dan memakai masker.

Penelitian menunjukkan penerapan protokol kesehatan yang paling susah untuk dilakukan adalah menjaga jarak, mereka tetap berkerumun di pasar, ditempat pernikahan, dan di acara-acara lainnya. Penerapan protokol kesehatan ini memang perlu pembiasaan untuk diterapkan dalam keluarga sehingga tidak hanya penderita Diabetes Mellitus DM nya yang menjaga kesehatan diri tetapi keluarga juga turut membantu dalam upaya pencegahan ini.

Teori dari Lawrence Green yang menyatakan bahwa pembentukan perilaku seseorang dapat dipengaruhi beberapa faktor salah satunya faktor predisposisi yaitu pengetahuan, sikap, motivasi, keyakinan dan nilai. Salah satu metode pembelajaran untuk merubah perilaku kesehatan adalah dengan pendidikan kesehatan. Untuk itu penerapan family health education perlu diberikan melalui pendekatan keluarga (family health education). Protokol kesehatan merupakan faktor eksternal yang penting untuk dilakukan karena merupakan bentuk dari upaya pencegahan terjadinya masalah gangguan kesehatan yang dapat diakibatkan oleh faktor lingkungan yang berpotensi merugikan kesehatan. Upaya ini harus dilakukan oleh individu, masyarakat, ataupun pemerintah untuk memperbaiki dan mencegah laju Covid-19.

Hasil penelitian menunjukkan terjadi peningkatan rata-rata penerapan protokol kesehatan antara sebelum dan sesudah intervensi dengan nilai beda mean 6,39. Adanya peningkatan pada hasil skor pre-test ke post-test yang cukup tinggi, terjadi karena 22 keluarga penderita Diabetes Mellitus (DM) sebelumnya sudah mendengarkan informasi terkait pencegahan penularan Covid-19 sehingga dapat membantu menerapkan protokol kesehatan yang baik. Hasil uji lebih lanjut menggunakan paired $t$ test didapatkan $\mathrm{p}=0,000$ yang berarti penerapan protokol kesehatan responden sesudah diberikan family health education menjadi lebih baik dari sebelum diberikan intervensi $(\mathrm{p}<0,05)$.

Family Health Education merupakan intervensi yang diberikan oleh peneliti kepada responden dengan metode penyuluhan pendekatan keluarga (door to door). Hasil penelitian menunjukkan peningkatan perubahan perilaku keluarga dalam menerapkan protokol kesehatan seperti mencuci tangan, menggunakan masker dan menjaga jarak. Metode pendekatan keluarga dapat mempengaruhi anggota keluarga lain untuk 
menerapkan protokol kesehatan bersama dengan baik.

Kondisi ini didukung dengan pendapat yang mengatakan bahwa family health education atau biasa kita sebut pendidikan kesehatan keluarga merupakan kegiatan pendidikan yang dilakukan dengan cara menyebarkan pesan, menanamkan keyakinan sehingga keluarga mampu memiliki kesadaran, mendapatkan pengetahuan dan juga dapat menerapkan anjuran yang ada hubungan dengan kesehatan (Fitriani, 2011).

Pendidikan kesehatan tidak dengan mudah disampaikan dari satu orang ke orang lain, perlu sebuah prosedur yang harus dilaksanakan atau suatu produk yang harus dicapai, tetapi merupakan proses perkembangan yang berubah secara dinamis, yang didalamnya menerima atau menolak informasi, sikap, maupun yang berhubungan dengan tujuan hidup sehat (Abadi, 2015).

Pendidikan kesehatan melalui pendekatan keluarga merupakan salah satu cara untuk memberikan atau menyampaikan pesan terkait informasi kesehatan yang dapat mengubah perilaku keluarga dalam menerapkan faktor eksternal yang juga dapat memberikan masalah kesehatan sehingga perlu adanya pendidikan kesehatan melalui keluarga (Notoatmodjo, 2018).

Berdasarkan penelitian yang dilakukan oleh (Halawa\&Nancye, 2016; Winda, et.al, 2018)diketahui adanya pengaruh yang signifikan antara pendidikan kesehatan terhadap diit pasien DM. Berdasarkan hasil penelitian ini dapat disimpulkan bahwa metode yang digunakan peneliti memberikan edukasi terkait Family Health Education dengan cara door to door atau langsung dari rumah ke rumah, sehingga hal ini menjadi efektif dikarenakan peneliti langsung bertatap muka dengan keluarga sekaligus adanya anggota keluarga yang sebagian juga ikut mendengarkan edukasi yang diberikan peneliti dan mampu menambah pengetahuan keluarga, maka dari sinilah informasi didapatkan dan dapat diterapkan oleh seluruh anggota keluarga pasien Diabetes Mellitus.

Selain itu peneliti juga memberikan poster terkait penerapan protokol kesehatan yang ditempel di masing-masing rumah agar keluarga selalu ingat untuk membaca sekaligus menerapkannya langsung. Kondisi ini didukung dengan adanya penelitian menurut (Muvida \&Palupi, 2018) sikap atau perilaku merupakan reaksi atau respon seseorang yang masih tertutup terhadap adanya stimulus atau objek, salah satu yang mempengaruhi sikap atau perilaku adalah pengetahuan yang dimiliki seseorang. Penyuluhan dengan media dapat meningkatkan pengetahuan sebesar $85,7 \%$. Selain itu pada penelitian ini mengatakan bahwa penyuluhan dilakukan secara door to door dengan menggunakan poster yang dibagikan ke responden dan metode yang digunakan pre-post test.

Edukasi yang diberikan kepada keluarga merupakan tugas utama petugas kesehatan terutama perawat. Peran ini merupakan peran utama yang harus dimiliki seorang perawat karena upaya inilah yang dapat memberikan pengetahuan kesehatan kepada masyarakat agar menambah pengetahuan masyarakat dan membuat mereka sadar sekaligus mampu menerapkan informasi kesehatan tersebut dalam kehidupan sehari-hari.

Peran peneliti pada penelitian ini salah satunya adalah peran promotif-preventif dengan cara memberikan sosialisasi kepada anggota keluarga dengan metode family health education (pendidikan kesehatan keluarga) terkait protokol kesehatan untuk mencegah penularan Covid-19 pada keluarga DM. Metode ini peneliti gunakan karena keluarga memiliki efek yang menyeluruh dimana jika satu keluarga memiliki masalah kesehatan maka anggota keluarga yang lain tidak menutup kemungkinan dapat memiliki masalah kesehatan yang sama, begitu juga adanya pemberian penyuluhan kesehatan, jika satu anggota keluarga memahami dan mampu memberikan contoh bagaimana menerapkan protokol kesehatan yang baik, maka keluarga yang lain juga akan mengikuti.

\section{KESIMPULAN DAN SARAN}

Family health education dapat meningkatkan penerapan protokol kesehatan pencegahan penularan Covid-19 pada keluarga dengan komorbid Diabetes Mellitus. Intervensi ini dapat diterapkan oleh petugas kesehatan yang ada di Puskesmas melalui kunjungan keluarga maupun saat klien dan keluarga berkunjung ke Puskesmas sebagai salah satu bentuk intervensi dalam menurunkan penularan Covid-19 terutama pada klien Diabetes Mellitus (DM) dan pemahaman keluarga terhadap pentingnya pengetahuan tentang penularan covid 19, yang mewujudkan sikap dan perilaku yang positif dan bermanfaat bagi keluarga dan masyarakat.

Sedangkan bagi pihak puskesmas, intervensi ini dapat dijadikan sebagai salah satu bentuk kegiatan yang rutin dilakukan atau menjadi salah satu program khususnya untuk program pemberantasan penyakit menular (P2M) untuk mengurangi laju peningkatan Covid-19. 


\section{REFERENSI}

Abadi, H. (2015). Pendidikan Kesehatan. Program Studi Ilmu Keperawatan Sekolah Tinggi Ilmu Kesehatan 'Aisyiyah Yogyakarta 2015.

Ali, M. 2010. Dasar - Dasar Pendidikan Kesehatan Masyarakat dan Promosi Kesehatan. CV. Trans Info Media, Jakarta.

Buana, Dana. (2020). Analisis Perilaku Masyarakat Indonesia dalam Menghadapi Pandemi Virus Corona (Covid-19) dan Kiat Menjaga Kesehatan Jiwa. Jurnal Sosial dan Budaya Syar'i. Vol. 7.

Burhan E, Susanto AD, Sally Nasution A dkk., 2020. Protokol tatalaksana COVID-19 edisi 1, Perhimpunan Dokter Paru Indonesia (PDPI), Perhimpunan Dokter Spesialis Kardiovaskular Indonesia (PERKI), Perhimpunan Dokter Spesialis Penyakit Dalam Indonesia (PAPDI), Perhimpunan Dokter Anestesiologi dan Terapi Intensif Indonesia (PERDATIN), dan Ikatan Dokter Anak Indonesia (IDAI), p 1-3.

Chandra B. (2012). Pengantar Kesehatan Lingkungan. Jakarta: EGC Buku Kedokteran. John Lede M , Hariyanto T, Ardiyani VM, 2018, Pengaruh kadar gula darah terhadap penyembuhan luka diabetes mellitus di desa dinoyo malang, Nursing News: Volume 3, Nomor 1: 539-549.

Kholis Ernawati, R. (2018). Penyuluhan cara pencegahan penularan tuberkulosis dan pemakaian masker di keluarga penderita: pengalaman dari Johar Baru, Jakarta Pusat. Journal Of Community Medicine and Public Health, Volume 34, 44-49.

Matheos, B., \& Rottie, J. (2018). No Title. EJournal Keperawatan, 6, Volume 6 no 1.

Muvida, F \& Palupi, M. (2018). Efektivitas Booklet Terhadap Tingkat Pengetahuan Gizi Pasien Diabetes Melitus pada Prolanis Puskesmas Srengat Kabupaten Blitar.

Diabetes Melitus. Jurnal Keperawatan, 5(1), 7 Pages. Retrieved from http://jurnal.stikeswilliambooth.ac.id/index.ph $\mathrm{p} / \mathrm{d} 3 \mathrm{kep} / \mathrm{article} / \mathrm{view} / 42$.
Fitriani. (2011). Promosi Kesehatan, (Graha Ilmu), Yogyakarta.

Halawa, A., \& Nancye, P. (2016). Pengaruh Pendidikan Kesehatan Tentang DM terhadap Kepatuhan Diet pada Penderita DM di Club .

Setiarni, S.M, Sutomo, A.H \& Hariyono, W. (2011). Hubungan antara Tingkat Pengetahuan, Status Ekonomi dan Kebiasaan Merokok dengan Kejadian Tuberkulosis Paru pada Orang Dewasa di Wilayah Kerja Puskesmas Tuan-Tuan Kabupaten Ketapang Kalimantan Barat. KES MAS Vol. 5, No. 3, September $2011:$ 162-232.

John Lede M , Hariyanto T, Ardiyani VM, 2018, Pengaruh kadar gula darah terhadap penyembuhan luka diabetes mellitus di desa dinoyo malang, Nursing News: Volume 3, Nomor 1: 539-549.

Kholis Ernawati, R. (2018). Penyuluhan cara pencegahan penularan tuberkulosis dan pemakaian masker di keluarga penderita: pengalaman dari Johar Baru, Jakarta Pusat. Journal Of Community Medicine and Public Health, Volume 34, 44-49.

Matheos, B., \& Rottie, J. (2018). No Title. EJournal Keperawatan, 6, Volume 6 no 1.

Muvida, F \& Palupi, M. (2018). Efektivitas Booklet Terhadap Tingkat Pengetahuan Gizi Pasien Diabetes Melitus pada Prolanis Puskesmas Srengat Kabupaten Blitar. Jurnal Gizi KH, Desember 2018, 1(1):58-64.

Notoatmodjo. (2018). Metodologi Penelitian Kesehatan (R. Cipta, Ed.). Jakarta.

Susilo A, Rumende M, Pitoyo CW et al., 2020, Coronavirus Disease 2019: Tinjauan Literatur Terkini (Coronavirus Disease 2019: Review of Current Literatures Jurnal Penyakit Dalam Indonesia | Vol. 7, No. 1, p 45-67.

Siswanjani, Bondan Palestin, and Maria H Bakri, (2018). Penerapan Pendidikan Kesehatan Diet Diabetes Pada Keluarga Dengan Klien Diabetes Melitus Di Wilayah Kerja Puskesmas Sewon II. skripsi thesis, Poltekkes Kemenkes Yogyakarta. 